\title{
АГРАРНЕ ПРАВО
}

\section{ВПЛИВ ЄВРОІНТЕГРАЦІЙНИХ ТА МІЖНАРОДНИХ ЗОБОВ'ЯЗАНЬ НА РОЗВИТОК АГРАРНОГО ЗАКОНОДАВСТВА УКРАЇНИ}

О. В. ГАФУРОВА, доктор юридичних наук, професор,

профессор кафедри аграрного, земельного та екологічного права імені академіка В.3. Янчука, Національний університет біоресурсів і природокористування України E-mail: gafurova.olena@gmail.com

Анотація. У статті проаналізовано вплив євроінтеграційних та міжнародних зобов'язань на розвиток аграрного законодавства України на прикладізаконопроектів, зареєстрованих у Верховній Раді України. 3 метою вирішення соціальних проблем селян, пропонується на законодавчому рівні закріпити поняття «соціальний розвиток сільських територій», а також окреслити заходи, за допомогою яких в межахполітики сільського розвитку, можуть бути вирішені соціальні проблеми села.

Доводиться необхідність розроблення та прийняття Загальнодержавноі програми сільського розвитку, яка мала б довгостроковий період виконання, здійснювалася центральними та місцевими органами виконавчої влади і затверджувалася Законом України. Вказане кореспондується із механізмом, який застосовується в рамках політики сільського розвитку ЄС.

Зазначається про необхідність використання у національному законодавстві усталеної термінології, з мінімальною кількістю слів іноземного походження, та забезпечення врахування особливостей, притаманних аграрному сектору економіки країни.

Ключові слова: аграрне законодавство, міжнародне законодавство, спільна сільськогосподарська політика $\in C$, сталий розвиток сільського господарства, сільський розвиток, соціальний розвиток села, державна аграрна політика, продовольча безпека

\section{Актуальність.}

У сучасних умовах українське аграрне законодавство переживає бурхливий розвиток, пов’язаний, у значній мірі, із глобалізаційними процесами, що відбуваються в світовій економіці, та інтеграцією України у Європейське Співтова-

14 | ISSN 2663-1350 «ПРАВО. ЛЮДИНА. ДОВКІЛЛЯ»| «LAW. HUMAN. ENVIRONMENT» Vol. 10, No 3, 2019 
риство. Крім того, суттєво погіршився рівень нормотворчої техніки, що безпосередньо вплинуло на його якість. Так, на думку представників аграрно-правової науки, аграрне законодавство стало обсяговим, колізійним, нерідко правові норми, що регулюють одні й ті самі аграрні відносини, дублюються в різних нормативно-правових актах. Його типовими недоліками є суперечності між новоприйнятими і чинними законами, між законами і підзаконними нормативно-правовими актами (Аграрне Право України, 2017: 47). Застосування такого законодавства ускладняється за рахунок наявності значного масиву спеціальних нормативно-правових актів, які безпосередньо є джерелами аграрного права, а також тих, які необхідно застосовувати у субсидіарному порядку. Вказана тенденція є характерною не тільки для України. Функціонування Спільної сільськогосподарської політики ЄС також вимагає прийняття численних нормативно-правових актів. Так, за кількістю джерел та приписів, що в них містяться, сільськогосподарське право вважається найбільш об'ємною галуззю права ЄС (за даними офіційної бази джерел права ЄC, кількість джерел сільськогосподарського права станом на 2011 р. складала більше 3000 найменувань (Право Европейского Союза, 2013: 591).

\section{Аналіз останніх досліджень ма публікацій.}

Проблемами розвитку українського аграрного законодавства займалися такі юристи-аграрники, як А.I. Брінцов, А.В. Духневич, В.М. Єрмоленко, Т.О. Коваленко, В.І. Семчик, А.М. Статівка, В.Ю. Уркевич, В.З. Янчук.

Mema cmammi полягає у дослідженні впливу євроінтеграційних та міжнародних зобов'язань на розвиток аграр- ного законодавства України на прикладі законопроектів, зареєстрованих у Верховній Раді України (далі - ВРУ).

\section{Результати.}

Частиною аграрного законодавства України є міжнародні договори, згода на обов'язковість яких надана ВРУ (п. 1 ст. 19 Закону України від 29 червня 2004 р. «Про міжнародні договори і угоди»). Як слушно зазначається у науковій літературі, міжнародно-правове регулювання аграрних відносин сприяє підвищенню ефективності аграрного виробництва шляхом розвитку торгівлі сільськогосподарською продукцією на світовому ринку та економічному співробітництву держав у цілому (Аграрне Право, 2018: 92). Крім того, на міжнародному рівні підвищується увага допроблеми забезпечення прав і свобод сільського населення. Так, одним із останніх документів, який у найближчому часі впливатиме не тільки на формування аграрної політики України, а й інших країн-членів ООН, є Декларація ООН про права селян і інших осіб, які працюють в сільських районах («Проект декларации ООН...», 2018), яку було схвалено на пленарному засіданні Генеральної Асамблеї ООН 17 грудня 2018 p. («UN rights chief welcomes...», 2018). Відповідно прийняття такого нормативного акту має стати серьозним поштовхом у напрямі не тільки перегляду предмету аграрного права, його принципів та системи, а й створення реально діючого механізму реалізації прав селян.

Також, варто врахувати i процес адаптації національного законодавства до законодавства ЄС. При цьому, слід звернути увагу, що Угодою про асоціацію між Україною, з однієї сторони, та Європейським Союзом, Свропейським співтовариством 3 атомної енергії і їхніми державами-членами, з іншої сторони, 
ратифікованою Законом України від 16 вересня 2014 р. передбачено, що регламенти, директиви, рішення, рекомендації та повідомлення $€ \mathrm{C}$, що містяться в додатках, $є$ частиною юридичних стандартів, які розглядаються Українською стороною при поступовому наближенні законодавства по конкретному сектору чи продукту. У сфері сільського господарства та розвитку сільських територій налічується 58 таких актів (Додаток XXXVIII до глави 17 розділу V). Відповідно, всі вони стають частиною українського аграрного законодавства.

У контексті вищезазначеного, хотілось би зупинитися на аналізі двох законопроектів, зареєстрованих у ВРУ, які розроблені з урахуванням євроінтеграційних та міжнародних зобов'язань України, та прямо або опосередковано стосуються розвитку аграрного сектору економіки. Перший з них - це проект Закону України за № 8171 «ро основні засади державної аграрної політики та державної політики сільського розвитку» («Про основні засади ...», 2018). Зокрема, ним передбачається визнання таким, що втратив чинність, Закону України від 17 жовтня 1990 р. «Про пріоритетність соціального розвитку села та агропромислового комплексу в народному господарстві» (п. 4 р. VI). Що ж пропонується авторами законопроекту для вирішення соціальних проблем на селі? 3'ясовується, що в цьому документі взагалі не йдеться про соціальний розвиток села або сільських територій, а тим більше забезпечення його пріоритетності. Автори застосовують поняття «сільський розвиток» - процес, при якому покращення якості життя та економічного благополуччя населення, що проживає у сільській місцевості, $\epsilon$ взаємопов'язаними та взаємозалежними (ст. 1). Таке визначення зводиться до констатації факту, що покращення якості життя безпосередньо пов'язане із економічним благополуччям населення. Вказаний підхід жодним чином не розкриває сутності сільського розвитку. Дуже схожим за змістом $\epsilon$ поняття сільського розвитку, що вживається в Концепції розвитку сільських територій, схваленій розпорядженням КМУ від 23 вересня 2015 р. № 995-р. Згідно з ним - це поліпшення якості життя та економічного благополуччя сільського населення. Але, для соціального розвитку села (сільських територій) також $є$ характерним поступове підвищення рівня і якості життя селянства. Тому, слід врахувати, що перше поняття передбачає задоволення широкого спектру економічних, екологічних та соціальних проблем 21-го століття («Rural development», 2014-2020). Тобто, для сільського розвитку є важливим соціальний аспект, але він розглядається як один із чинників, що забезпечують такий розвиток. Вказаний висновок підтверджується аналізом Плану заходів 3 реалізації цієї Концепції, затвердженого розпорядженням КМУ від 19 липня 2017 р. № 489-р. У цьому документі перераховуються наступні напрями, за якими мають вживатися відповідні заходи: підвищення якості життя сільського населення; охорона та збереження природних ресурсів у сільській місцевості; диверсифікація та розвиток сільської економіки; удосконалення системи управління сільськими територіями; освіта та інформаційно-консультаційне забезпечення.

Отже, у процесі проведення подальшої роботи над згаданим законопроектом, необхідно, принаймні, уточнити визначення поняття «сільський розвиток» та закріпити поняття «соціальний розвиток сільських територій», а також чітко окреслити заходи, за допомогою яких в межах політики сільського розвитку, можуть бути вирішені саме соціальні проблеми села.

16 | ISSN 2663-1350 «ПРАВО. ЛЮДИНА. ДОВКІЛЛЯ»| «LAW. HUMAN. ENVIRONMENT» Vol. 10, No 3, 2019 
Законопроектом пропонується окремий механізм реалізації його положень. Він передбачає розробку Міністерством аграрної політики і продовольства України Плану заходів з реалізації основних засад розвитку державної аграрної політики та політики сільського розвитку. Такий План включає: завдання i заходи; індикатори оцінки результативності виконання завдань і здійснення заходів; строки забезпечення виконання завдань і здійснення заходів; фінансове забезпечення виконання завдань і здійснення заходів. Він розробляється на п'ять років та затверджується КМУ (ст. 21). Не зрозуміло, яким чином держава збирається гарантувати виконання вищезазначеного Плану заходів? Адже законопроект не встановлює ефективної системи контролю та будь-яку відповідальність за невиконання такого Плану. Крім того, виникає питання щодо ролі державних цільових програм і взагалі програмування в управлінні сільським розвитком. Оскільки в законопроекті про це не йдеться. Але, спочатку має розроблятися відповідна програма, а потім - план заходів по їі виконанню. Враховуючи вищезазначене, необхідним $є$ розроблення та прийняття Загальнодержавної програми сільського розвитку, яка мала б довгостроковий період виконання, здійснювалася центральними та місцевими органами виконавчої влади i затверджувалася Законом України. Відповідальність за іï виконання слід покласти на Міністерство аграрної політики та продовольства України. Цей документ має передбачати окремий розділ, присвячений вирішенню соціальних проблем сільських територій. Розвиток аграрного законодавства у такому напрямі дозволить забезпечити пріоритетність соціального розвитку села в аграрному секторі економіки країни. Вказане кореспондується із механізмом, який застосовується в рамках політики сільського розвитку ЄС. Так, правове регулювання відносин у сфері сільського розвитку здійснюється шляхом прийняття на семірічний період «програмних документів» (Національних та/або регіональних програм сільського розвитку (rural development programmes (RDPs) (ст. 6 Регламенту Свропейського Парламенту і Ради від 17 грудня 2013 р. № 1305/2013 щодо підтримки сільського розвитку Європейським сільськогосподарським фондом сільського розвитку (EAFRD) та відміни Директиви Ради № 1698/2005) («Regulation (EU) on support for rural development...», 2013).

Другий - це проект Закону України за № 9015 «Про Стратегію сталого розвитку України до 2030 року» («Про Стратегію сталого розвитку.....», 2018) (далі - проект Стратегіi). У ньому сформульовано стратегічну ціль 2: «забезпечення сталого галузевого та регіонального розвитку» (сприяння сталому розвитку агропромислового комплексу становить лише одну 3 операційних цілей (2.1.). При такому підході повністю «випадають» такі складові цілі 2 Резолюції, прийнятої Генеральною Асамблеєю ООН 25 вересня 2015 р. «Перетворення нашого світу. Порядок денний у сфері сталого розвитку на період до 2030 року» (далі - Резолюція) («Перетворення нашого світу...», 2015), як необхідність викорінення голоду, забезпечення продовольчої безпеки та покращення харчування.

Крім того, слід вказати, що одним iз пріоритетів політики ЄС визначено «соціальні виклики» (зокрема: продовольча безпека, стале сільське та лісове господарство, прибережний, морський і внутрішній водний ресурс та біоекономіка (ч. III Додатку I Рамкової Програми ЄС 3 досліджень та іновацій «Горизонт 2020») («Regulation (EU) establishing 
Horizon 2020...», 2013). Причому, сталий розвиток сільського та лісового господарства передбачає здійснення діяльності, зосередженої на розробці послуг, концепцій та політик, спрямованих на підвищення сільського добробуту та сприяння сталому споживанню (п. 2.3. ч. ІІІ). Тобто, сталий розвиток сільського господарства розглядається у широкому розумінні та у безпосередній єдності із забезпеченням продовольчої безпеки країн СС. Враховуючи зазначене, а також стан забезпечення продовольчої безпеки в Україні, вважаємо за доцільне привести проект Стратегії у відповідність із міжнародними нормативно-правовими актами.

Нажаль, слід констатувати, що зміст стратегічної цілі 2 являє собою дослівний переклад відповідної частини Резолюції, без адаптації термінів до українського юридичного термінологічного апарату. Наприклад, «виробники аграрної продукції» (в українському законодавстві усталеним $є$ поняття «сільськогосподарські товаровиробники»), «фермерські сімейні господарства» (в українському законодавстві - «сімейні фермерські господарства»). Що ж стосується таких категорій як «скотар» та «рибалка», то взагалі не зрозуміло, що вкладають автори законопроекту у їх зміст! Цікаво, що всіх цих суб'єктів, а також жінок (!) віднесено до дрібних виробників аграрної продукції. При цьому відсутне будьяке обгрунтування для вказаного узагальнення. Крім того, проект Стратегії оперує таким поняттям, як «малі сільськогосподарські підприємства (до 50 га земельних угідь)». Що ж мається на увазі під вказаним терміном: юридичні або фізичні особи? Які мають у власності або користуванні відповідні земельні ділянки? Чи знайдеться серед них місце для власників особистих селян- ських господарств, які на сьогоднішній день $є$ основними виробниками сільськогосподарської продукції? Тобто, в законодавстві має використовуватися усталена термінологія, з мінімальною кількістю слів іноземного походження, та забезпечуватися врахування особливостей, притаманних аграрному сектору економіки країни.

Уявляється не зовсім коректним встановлення у проекті Стратегії завдання щодо «необхідності припинення до 2020 р. незаконного вирощування генетично модифікованих рослин та використання генетично модифікованих організмів». Адже, вказане положення може трактуватися неоднозначно. 3 одного боку, якщо йдеться про встановлення факту правопорушення, то винна особа має нести за нього відповідальність у порядку, передбаченому чинним законодавством. 3 іншого боку, складається враження, що автори законопроекту вважають діяльність в зазначеній сфері незаконною, всупереч Закону України від 31 травня 2007 р. «Про державну систему біобезпеки при створенні, випробуванні, транспортуванні та використанні генетично модифікованих організмів».

Потребує уточнення пропозиція щодо «необхідності урізноманітнення ринкових інструментів (страхування, гарантійні фонди, форвардна торгівля, торгівля деривативами, електронна торгівля тощо), використання механізмів проведення товарних і фінансових інтервенцій». Механізм роботи вказаних «ринкових інструментів» розроблений, зокрема, на підставі Законів України від 24 червня 2004 р. «Про державну підтримку сільського господарства України» та від 9 лютого 2012 p. «Про особливості страхування сільськогосподарської продукції $з$ державною підтримкою».

18 | ISSN 2663-1350 «ПРАВО. ЛЮДИНА. ДОВКІЛЛЯ» | «LAW. HUMAN. ENVIRONMENT» Vol. 10, No 3, 2019 


\section{Висновки і перспективи.}

Формування національного законодавства у сфері сільського розвитку відбувається під безпосереднім впливом євроінтеграційних та міжнародних зобов'язань України. При їх виконанні мають враховуватися особливості, притаманні аграрному сектору економіки країни та забезпечуватися сприятливі умови для подальшого розвитку національного сільськогосподарського виробництва, вирішення соціальних проблем сільського населення і підвищення якості життя на сільських територіях. Для реалізації цих завдань необхідним є розроблення та прийняття Загальнодержавної програми сільського розвитку, яка мала б довгостроковий період виконання, здійснювалася центральними та місцевими органами виконавчої влади і затверджувалася Законом України. Вказане кореспондується із механізмом, який застосовується в рамках політики сільського розвитку ЄС.

\section{Список використаних джерел}

1. Аграрне право: підручник. За ред А.М. Статівки. Харків: Право, 2018. 416 с.

2. Аграрне право України: навчальний посібник. За ред. Т.Є. Харитонової та І.І. Каракаша. Одеса: Юридична література, 2017. 436 c.

3. Право Европейского Союза в 2-х т.: учеб. для бакалавров. Под ред. С.Ю. Кашкина. 4-е изд., перераб. и доп. Т. 2: Особеннаячасть. Москва: Юрайт, 2013. 1023 с.

4. Проект декларации ООН о правах крестьян и других лиц, работающих в сельских районах. URL: https://www. ohchr.org/Documents/HRBodies.

5. Проект Закону України від 23 березня 2018 р. № 8171 «Про основні засади державної аграрної політики та державної політики сільського розвитку».
URL: http://w1.c1.rada.gov.ua/pls/zweb2/ webproc4_1?pf3511=63695

6. Проект Закону України від 7 серпня 2018 р. № 9015 «Про Стратегію сталого розвитку України до 2030 року». URL: http://w1.c1.rada.gov.ua/pls/zweb2/ webproc4_1?pf3511=64508

7. Резолюція, прийнята Генеральною Асамблеєю ООН 25 вересня 2015 р. «Перетворення нашого світу. Порядок денний у сфері сталого розвитку на період до 2030 року»..URL: http://sdg.org.ua/ua/ resources-2/344-2030-2015

8. Regulation (EU) № 1291/2013 of the European Parliament and of the Council of 11 December 2013 establishing Horizon 2020 - the Framework Programme for Research and Innovation (2014-2020) and repealing Decision № 1982/2006/EC (Text with EEA relevance). URL: http://eur-lex.europa.eu

9. Regulation (EU) № 1305/2013 of the European Parliament and of the Council of 17 december 2013 on support for rural development by the European Agricultural Fund for Rural Development (EAFRD) and repealing Council Regulation (EC) № 1698/2005.URL: http://eur-lex. europa.eu

10. Rural development 2014-2020. URL: https://ec.europa.eu/agriculture.

11. UN rights chief welcomes new text to protect rights of peasants and other rural workers. URL: https://news.un.org/en/ story/2018/12/1028881

\section{References}

1. Ahrarne pravo [Agrarian Law] (2018). Za red A.M., Stativky. Kharkiv: Pravo, 416.

2. Ahrarne pravo Ukrainy [Agrarian Law of Ukraine] (2017). Za red. T.Ye., Kharytonovoi \& I.I., Karakasha. Odesa: Yurydychna literatura, 436.

3. Pravo Evropeiskoho Soiuza [European Union law] (2013). Pod red. S.Yu., Kashkyna. T. 2: Osobennaia chast. Moskva: Yurait, 1023. 
4. Proekt deklaratsyy OON o pravakh krestian y druhykh lyts, rabotaiushchykh $v$ selskykh raionakh [Draft UN Declaration on the rights of peasants and other people working in rural areas] (2018). Available at: https://www. ohchr.org/Documents/HRBodies.

5. Proekt Zakonu Ukrainy 23.03.2018 № 8171 «Pro osnovni zasady derzhavnoi ahrarnoi polityky ta derzhavnoi polityky silskoho rozvytku» [Draft Ukraine Law of 23.03.2018 № 8171 «About Basic Principles of State Agrarian Policy and State Policy of Rural Development»] (2018). Available at: http://w1.c1.rada.gov.ua/pls/zweb2/webproc4_1?pf3511=63695.

6. Proekt Zakonu Ukrainy 07.08.2018 № 9015 «Pro Stratehiiu staloho rozvytku Ukrainy do 2030» [Draft Ukraine Law of 07.08.2018 № 9015 «About Strategy of Ukraine Sustainable Development until 2030»] (2018). Available at: http://w1.c1.rada.gov.ua/pls/ zweb2/webproc4_1?pf3511=64508.

7. Rezoliutsiia, pryiniata Heneralnoiu Asambleieiu OON 25.09.2015 «Peretvorennia nashoho svitu. Poriadok dennyi u sferi staloho rozvytku na period do 2030 » [Res- olution adopted by the General Assembly on 25.09.2015. Transforming our world: the 2030 Agenda for Sustainable Development] (2015). Available at: http://sdg.org. ua/ua/resources-2/344-2030-2015.

8. Regulation (EU) No. $1291 / 2013$ of the European Parliament and of the Council of 11 December 2013 establishing Horizon 2020 - the Framework Programme for Research and Innovation (2014-2020) and repealing Decision No 1982/2006/EC (Text with EEA relevance). Available at: http://eur-lex.europa.eu.

9. Regulation (EU) No. 1305/2013 of the European Parliament and of the Council of 17 december 2013 on support for rural development by the European Agricultural Fund for Rural Development (EAFRD) and repealing Council Regulation (EC) No 1698/2005. Available at: http://eur-lex.europa.eu

10. Rural development 2014-2020. Available at: https://ec.europa.eu/agriculture/rural-development-2014-2020_en.

11. UN rights chief welcomes new text to protect rights of peasants and other rural workers. Available at: https://news.un.org/en/story/2018/12/1028881

\section{O.V. Hafurova (2019). Influence of the euro-integration and international obligations on the agricultural legislation of Ukraine. Law. Human. Environment, 10(3): 14-20. https://doi.org/10.31548/law2019.03.002}

Summary. The article analyzes the impact of European integration and international commitments on the development of Ukrainian agricultural legislation on the example of draft laws registered at the Verkhovna Rada of Ukraine. In order to solve the social problems of the peasants, it is proposed at the legislative level to consolidate the concept of "social development of rural territories", as well as outline the measures by which, in the framework of rural development policy, social problems of the village can be solved.

The necessity of the development and adoption of the National Rural Development Program, which would have a long-term implementation period, was carried out by central and local executive authorities and approved by the Law of Ukraine. The indicated corresponds to the mechanism used within the framework of EU rural development policy.

It is stipulated the necessity to use the established terminology in the national legislation, with a minimum number of words of foreign origin, and to ensure that account is taken of the peculiarities inherent in the agricultural sector of the country's economy.

Keywords: agrarian law, international law, EU mutual agricultural policy, sustainable development of agriculture, rural development, rural social development, state agricultural policy, food safety 